\title{
Chaerophyllum coloratum L.: Essential Oils of Ripe Fruits and Umbels
}

\author{
Vlatka Vajs \\ Institute of Chemistry, Technology and Metallurgy \\ Njegoseva 12, YU-11000 Belgrade, Yugoslavia \\ Slobodan Milosavljevic ${ }^{*}$ and Vele Tesevic \\ Faculty of Chemistry, University of Belgrade \\ Studentski trg 16, YU-11001 Belgrade, Yugoslavia \\ Predrag Zivanovic, Radisa Jancic, Branislava Todorovic and \\ Violeta Slavkovska \\ Faculty of Pharmacy, University of Belgrade \\ Vojvode Stepe 450, YU-11000 Belgrade, Yugoslavia
}

Received: December 1994

ABSTRACT: Essential oils of ripe fruits and umbels of Chaerophyllum coloratum L. (Apiaceae) were found by GC and GC/MS to contain very high percentage of (E)- $\beta$ farnesene $(79.21 \%$ and $68.40 \%$ respectively).

KEY WORD INDEX: Chaerophyllum coloratum, Apiaceae, essential oil composition, (E)- $\beta$-farnesene.

INTRODUCTION: The Chaerophyllum genus (ca. 40 species) occurs commonly throughout Europe, Asia and northern America (1). Chaerophyllum coloratum L. is a species which is endemic in the Adriatic countries where it can be found in the rocky submediterranean areas, such as mountain Prokletije (Kosovo, Serbia), Croatia, Herzegovina, Montenegro and Albania (1,2). Analysis of essential oils of ripe fruits and umbels of this species is reported in this paper.

EXPERIMENTAL: Ripe fruit and umbels of Chaerophyllum coloratum were collected from the vicinity of Herceg Novi (Montenegro) in July 1994. A voucher specimen of the plant is kept at the Faculty of Pharmacy, Belgrade University, Yugoslavia.

Isolation Procedure - The essential oil samples were isolated from $100 \mathrm{~g}$ of air-dried ground ripe fruits and umbels of $C$. coloratum, using the standard hydrodistillation Clevenger-type procedure (3). The oils were analyzed on a capillary GC and GC/MS, and

"Address for correspondence 
Table I. Percentage composition of essential oils of Chaerophyllum coloratum

\begin{tabular}{|c|c|c|}
\hline \multirow[b]{2}{*}{ Compound } & \multicolumn{2}{|c|}{ Plant part } \\
\hline & Ripe fruits & Umbels \\
\hline$\alpha$-pinene & 1.21 & 0.36 \\
\hline$\beta$-pinene & 6.95 & 1.51 \\
\hline (Z)- $\beta$-ocimene ${ }^{*}$ & 4.29 & 5.51 \\
\hline (E)- $\beta$-ocimene & 1.62 & 1.81 \\
\hline p-cymene & 0.35 & 0.78 \\
\hline$\alpha$-terpinolene & 0.42 & 0.73 \\
\hline$\beta$-caryophyllene & 1.04 & 1.04 \\
\hline (E)- $\beta$-farnesene ${ }^{\star}$ & 79.21 & 68.46 \\
\hline Total & 95.09 & 80.20 \\
\hline
\end{tabular}

most constituents were identified by comparison of their mass spectra to those from the MS library (4), taking into account the relative retention times. The structures of the main compounds were also verified by ${ }^{\mathrm{l}} \mathrm{H}-\mathrm{NMR}$ and IR data of the samples isolated by preparative GC.

Analytical GC-A Varian model 3400 gas chromatograph equipped with a split/splitless injector $\left(250^{\circ} \mathrm{C}\right)$ and a $30 \mathrm{~m} \times 0.32 \mathrm{~mm}$ DB-Wax fused silica capillary column and FID $\left(300^{\circ} \mathrm{C}\right)$, was used for $\mathrm{GC}$ and $\mathrm{GC} / \mathrm{MS}$ measurements. The column was temperature programmed as follows: $50^{\circ} \mathrm{C}(3 \mathrm{~min})$ and then $50^{\circ}-200^{\circ} \mathrm{C}$ at $10^{\circ} \mathrm{C} / \mathrm{min}$; carrier gas $3 \mathrm{~mL}$ $\mathrm{H}_{2} /$ min. Peak areas were calculated electronically by a Varian DS-604 data station.

GC/MS - The gas chromatograph was connected via an open split interface and a fused silica capillary (at $250^{\circ} \mathrm{C}$ ) to the ion source of a Finnigan MAT 8230 mass spectrometer, equipped with a PDP 11/74 computer. Working conditions: carrier gas $2 \mathrm{~mL} \mathrm{He} / \mathrm{min}$; other GC conditions as above. MS: ion source (electron impact), $170^{\circ} \mathrm{C}, 70 \mathrm{eV}$.

Preparative $\mathbf{G C}$-All preparative separations were performed using a Varian Aerograph 920 instrument, equipped with $\operatorname{TCD}\left(210^{\circ} \mathrm{C}\right)$ and a $2 \mathrm{~m} \times 4 \mathrm{~mm}$ glass column packed with $10 \%$ Carbowax $20 \mathrm{M}$ on Chromosorb W (60-80 mesh). Working conditions: Injector temperature $220^{\circ} \mathrm{C}$; oven temperature $120^{\circ} \mathrm{C}$ and $140^{\circ} \mathrm{C}$ (isothermal conditions); carrier gas, $25 \mathrm{~mL} \mathrm{H} / \mathrm{min}$. Samples (ca. $50 \mu \mathrm{L}$ ) were repeatedly injected and fractions were collected at the outlet of the detector in ice-cooled U-tubes.

${ }^{1} \mathrm{H}-\mathrm{NMR}$ spectra of the isolated compounds were measured in $\mathrm{CDCl}_{3}$ on a Varian FT 80A NMR spectrometer (at $80 \mathrm{MHz}$ ). IR spectra were recorded in the form of liquid films on a Perkin-Elmer 457 grating spectrometer.

RESULTS AND DISCUSSION: The essential oils (pale yellow) were isolated from ripe fruits and umbels in yields of $1.1 \%$ and $1.0 \%$ (calculated per weight of dried plant material), respectively. Both samples exhibited very similar chemical composition (Table I), i.e. mono- and sesquiterpene hydrocarbons with (E)- $\beta$-farnesene as dominating constituent (79.21\% and $68.46 \%$ in fruits and umbels, respectively). This compound was positively identified by comparison of its mass, IR and ${ }^{1} \mathrm{H}-\mathrm{NMR}$ spectra to those reported 
for (E)- $\beta$-farnesene $(5,6)$. Among the monoterpenes, the major constituents were $\beta$-pinene $(6.95 \%)$ and $(\mathrm{Z})-\beta$-ocimene $(5.51 \%)$ in fruits and umbels, respectively. Since, according to the available GC/MS data, the identity of $(Z)-\beta$-ocimene could not be firmly established, it was isolated from the oils by preparative GC and identified by comparison of its ${ }^{1} \mathrm{H}-\mathrm{NMR}$ and IR spectra to those previously published (7). The oil originating from umbels showed higher content of (not identified) high-boiling fractions, eluting after (E)-B-farnesene.

ACKNOWLEDGMENTS: This work was supported by a grant from the Serbian Ministry of Science and Technology.

\section{REFERENCES}

1. V Nikolic, Flore de la Republique Socialiste de Serbia. Ed. M. Josifovic, Vol. 5, pp 327-334, Academie Serbe des Sciences et des Arts, Belgrade (1973).

2. C. Silic, Endemic Plants. 2nd Edn, p 80, Svjetlost, Sarajevo (1988).

3. Pharmacopea Jugoslavica, 4, 126 (1984).

4. NBS Library/Wiley (1984).

5. E.F.L.J. Anet, Synthesis of (E,Z)- $\alpha$-, and (Z)-ק-farnesene. Aust. J. Chem., 23, 2101-2108 (1970).

6. K. E. Murray, $\alpha$-Farnesene: Isolation from the natural coating of apples. Aust. J.Chem., 22, 197204 (1969).

7. G. Ohloff, J. Seibl and E. Sz. Kovats, Zur Kenntnis ätherischer Öle, III - Die $\alpha$-Verbindungen acyclischer Monoterpene. Liebigs Ann. Chem., 675, 83-99 (1964). 